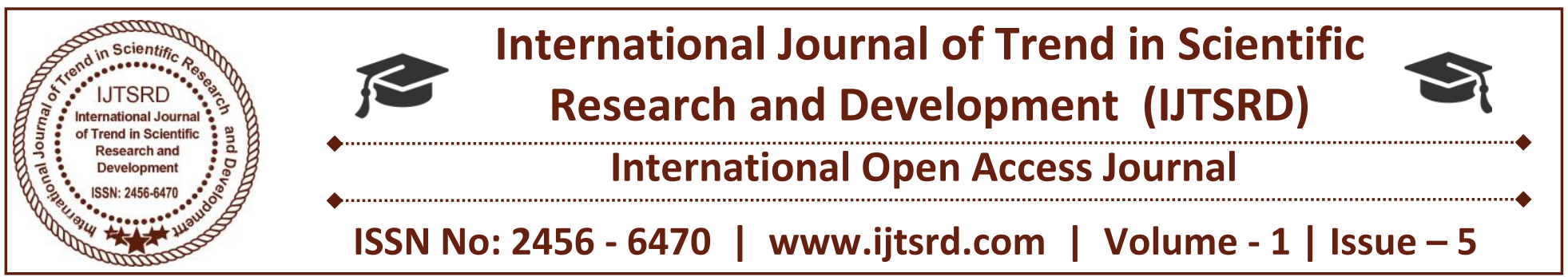

\title{
Educational Development and Nation Building in Nigeria, 1842-2015
}

\author{
S. I Okoro, \\ Ph. D, Department of History and International Relations \\ Ebonyi State University, Abakaliki
}

\begin{abstract}
\end{abstract}
Education, a process by which the community seeks to open its life to all the individuals within it, and to pass on to them its culture, including the standards by which it would have them live, came to Nigeria through three main avenues --Islamic religion, British colonial administration and Christian missionary agencies. The first, Islamic religion or Koranic education came rather inadvertently, following the penetration of Islam to the Kanen Bornu Empire, and the Hausa states in the $11^{\text {th }}$ and $14^{\text {th }}$ centuries respectively. The second and the third avenues were by deliberate administrative and missionary designs aimed at achieving defined objectives. This paper seeks to interrogate the place of the education that was introduce by these various means into what was to become Nigeria in the early 20th century with the aim of establishing to what extent it has aided the development of Nigeria and advanced nation-building process. It further examines what institutions were established by the modern educational system in the country, and what impacts these institutions have had on the developmental trajectory of the country. A historical methodology of analysis that is thematic, chronological and descriptive is adopted, while the instrumentalist paradigm of social analysis is employed.

Keyword: Education, Development, Nation-Building, Nigeria, Instrumentalism

\section{INTRODUCTION}

By the turn of the $19^{\text {th }}$ century what started in the middle of that century in the form of military assault on Lagos in 1851 had culminated into a virtual total annexation of what was to subsequently become Nigeria by a foreign power-the British. By 1900, save for some minor 'irritants' in the form of commercial and ritual resistance by a hinterland people of the Igbo South east, the entire country had passed unto the British as a colonial territory.

With this development, Nigeria was opened up for Western type educational system which was different in diverse respects from the indigenous forms of education that the people had known for centuries. Whereas the Western type educational system appeared some-what restricted to the southern part of the country, the North held on to its Islamic tradition with its attendant Quranic or Koranic education. This educational dichotomy has had important developmental impact on the Nigerian state. Our purpose here is to determine the extent of this impact by focusing on the different educational systems. Effort is equally made to highlight the institutions established in pursuit of these educational systems and what impact they have made to national development and nation-building. We look at this through the two major divides in the country: North and South.

\section{Educational Development in the North}

Education was introduced into Northern Nigeria by the British colonial administration. ${ }^{1}$ It was designed to serve prescribed administrative ends. Consequently, educational practices in the North were directed towards those objectives. It should be understood that before the introduction of the Western type 
educational system, Northern Nigeria had an established, but "amorphous system of Islamic religious (Koranic) schools, ${ }^{2}$ or education. Though we are concerned with the introduction and development of Western education in the North presently, it is difficult not to relate to the aforementioned, Islamic/Koranic education if we must gain a background and wholistic knowledge of the situation. The education that was introduced by the British colonial administration was more or less superimposed on structures upon which the Islamic education had stood, and was still standing at the point of the introduction.

In introducing that educational system, the British took cognizance of certain factors that tended to differentiate the North from the South. They include: (1) The fact that the North had established, if amorphous system of Islamic religious/Koranic schools; (2) The British administration believed that the North had achieved a higher state of civilization, which demanded that the social hierarchy that separated its indigenous ruling class from the masses be maintained, and the ruling class preserved.

Consequent upon these considerations, the administration tried to prevent any external influences that could interfere with the religious and social institutions. Perhaps, one of the most important of these factors that influenced education in the North was the prior establishment of education in the South, the result of which was often viewed with disdain by leading colonial administrators. Efforts were thus not spared in ensuring that the same consequences were not allowed to result from such introduction in the North. Before British annexation, Koranic schools existed for all and sundry, young, old, male, female, irrespective of status in society. Local mosques and praying sites usually served as schools. In such schools, in addition to memorizing portions of the Koran, pupils learnt to read and write in Arabic characters. The curriculum covered the correct forms of worship, emphasis on clean habits, obedience to superiors in the society, the fear of God and love for fellow men.

There may be need to attempt a brief presentation of the basic features of the Islamic/koranic education system to assure proper understanding of the one introduced by the British colonialists.

\section{The Almajiri and Arabic/Islamic System of Education in Northern Nigeria}

As the language of the Koran, Arabic is of great spiritual value. As a commentator noted, "the history of the teaching of Arabic throughout the Islamic world, but particularly in non Arab world, has been the history of the spread of Islam". ${ }^{3}$ By reason of this, elementary Arabic schools that developed in Northern Nigeria consequent upon the spread of the Islam to that part of the country in the $11^{\text {th }}$ and $14^{\text {th }}$ centuries were called koranic schools. Both Arabic and Islam were taught simultaneously.

Two types of Quaranic/Koranic schools subsequently developed in Northern Nigeria: 'Makarantar allo' or Tablet School and 'Makarantar Ilim' or the Higher School. The first, according to A.B Fafunwa, is for beginners, while the higher school embraces all aspects of Islamic learning. ${ }^{4}$ when a child begins to learn Arabic, it is with an intention of being able to read the Quar'an. Thus the basic school open to a Muslim child in Northern Nigeria was the 'Makarantar Allo', where Arabic characters were taught and memorized.

In deference to one of the Islamic traditions, which states that the best man among you is one who learns the Quari'an and then cares to teach it, Islamic learning started on this prophetic counsel ${ }^{5}$. Consequent upon this, the teaching of religion came to be seen as a sacred duty for which one should not expect an earthly reward. The teaching and learning of the Quaran and Arabic language thus started in Northern Nigeria, where the teacher depended for his living on charity or "sadagah". The teacher became one of the persons to whom 'sadagah' was prescribed - 'Fi Sabil Allah' - (in the way of Allah) ${ }^{6}$.

The teacher or 'Mu'allim' had to wander from place to place looking for charitable Muslims to patronize him by giving him food and shelter. Whenever he could not procure these bare necessities himself, he would send his pupils to go from door to door asking for charity. These pupils or students were considered to be 'muhajirun' or emigrants who had left their homes and followed the teacher 'muallim' in search of knowledge. This was the basis of the Almajiri institution in Northern Nigeria today.

According to Salim Bashir Magashi, the Hausa word 'almajiri' denotes different things depending upon the 
context and perspective. Originally, according to him, it was derived from the Arabic term 'almuhajir, meaning 'a migrant'. ${ }^{7} \mathrm{He}$ goes on to state that in the Nigerian context, it could mean a boarding student of Islamic studies, a student learning the science of the Quar'an, believed to be the revealed book of Almighty God, while committing the book to memory, a small child sent to an itinerant teacher to learn not just Islamic religion, but also how to pursue a means of livelihood for himself, his teacher, and the family; or even, to many uniformed Nigerians, a begger. ${ }^{8}$ In Hausa, almajiri means 'child student', almajirai, is its plural form, while almajiranci is the process or practice of learning, traveling and all other things that come with travelling.

Almajiranci was thus a version of system of education which was, and is still practiced in Northern Nigeria, an informal Islamic system, exclusively for boys, which started with the coming of Islam, before the coming of European powers and Western models of education. Lord Lugard asserted that by 1914, more than 24,000 almajiri schools existed in Northern Nigeria ${ }^{9}$. It is reported that the almajiri system reached its peak between 1804 and 1903 under the Sokoto Caliphate. It was therefore upon this system ${ }^{10}$, that Lord Lugard superimposed the Western educational system in the early $20^{\text {th }}$ century. As we proceed to consider the educational system brought on Northern Nigeria or Hausaland by the Colonialists, we reserve comments on the impacts of the institution of the almajiri system on national development and nation-building.

\section{The Introduction and Consolidation of Western Education in Northern Nigeria}

When Britain annexed Northern Nigeria from a British Chartered Company - the Royal Niger Company, in 1900, it was prompted by several factors. These factors included the need to limit the expansion of the French and German colonization schemes, humanitarian motives of stopping the slave trade and the desire to secure a vast fertile hinterland for British Merchants. ${ }^{11}$ It took Lord Lugard, an able soldier and tested administrator 3 years to conquer the Emirs and bring the territory under effective British administration. The world of the 1900s was not a most auspicious one for Britain to directly govern this vast territory of over $250,000 \mathrm{Km}^{2}$. Mr. Lugard therefore settled for the expediency of utilizing certain tested forms and practice of indigenous rule to establish
British suzerainty. This was the indirect rule system. In justifying Lugard's choice for indirect rule for the Northern territories, E. D Morel counseled:

To reduce them (the native Emirs) to impotence, to scatter their power, to break the organization they have created into small pieces would be politically foolish, practically unwise, morally unjust, and imperially disastrous. To strengthen their rule where weak, to perfect it where oppressive, to assist them, work with them, and through them along their natural lines; to interfere as little as possible with the customs and habits of themselves and their people; to respect their religious beliefs, to work gradually, peacefully, tactfully, for the attainment of the only conceivable objects which have taken us to their country- commercial development, advancement, prosperity- those should be the political principles guiding us in Northern Nigeria. $^{12}$

Lord Lugard now proceeded to work out plans for the effectives administration of the new territory. These plans covered such areas as taxation, justice, land, and administration, which also included education ${ }^{13}$, which concerns us here.

Generally, however, the indigenous structure of governance was retained. But a new British hierarchical bureaucracy consisting of a High Commissioner (later. Governor), Rresidents, District and Assistant District Officers, was super- imposed over it. The Emirs' powers were severely curtailed for they could no longer levy taxes, keep armies, initiate legislation, name their successors or wield executive power of any sort. In a nut- shell, they became a new type of civil servant. As Lord Lugard himself noted:

The native Chiefs are constituted as integral part of the machinery of the administration. There are not two sets of rulers - British and native and the Chief himself must understand that he has no right to place and power unless he renders his proper services to the state. ${ }^{14}$

This system which covered diverse areas of society was introduced into Northern Nigeria by Lord Lugard in order to develop the country and its native Emirs along lines of natural growth. There was an 
understanding that in time (not however specified) those rulers would be entrusted the governance of their own people possibly without British guidance. For future generations of enlightened rulers to emerge, the Emirs' sons were to be given the first and best choice in education. Being considered as the best way to perpetuate Indirect Rule, it became the overriding concern of the administration in its design and implementation of its educational policy. The intention of the British administration to govern Northern Nigeria indirectly through its Chiefs and emirs was thus seen as one of the reasons that made the government to seek to monopolize education in the Muslim areas of the country.

\section{Education, an Imperative Factor in the Policy of Indirect Rule}

Let us, rendered wise by experience, set our faces like flint against the Europeanizing of Northern Nigeria In Sierra Leone, in the Gold Coast, in the Western Provinces of Southern Nigeria, we have daily object lesson of the deplorable results of this denationalizing process. That Northern Nigeria should be preserved from it must be the earnest wish of all who are acquainted with its peoples and alive to its responsibilities. ${ }^{15}$

The above counsel was to form the fulcrum upon which British colonial education policy for northern Nigeria rested. It is common knowledge that the colonial government was dissatisfied with the role of educated Southerners who it accused of writing critical articles in Lagos newspapers, and other forms of agitation in the Lagos Colony and Protectorate of Southern Nigeria. We observe that even highly placed Southern Nigerians in Lagos appeared equally critical of educated Southerners. A Nigeria, Mr., later Dr. Henry Carr, the first Acting Director of Education for the Southern Provinces has this to say of the educated Southerners:

Not only is their stock of positive knowledge altogether inconsiderable on leaving school, but there is hardly a sign of the growth of mental power or of self - control. They are generally not intelligent, not reliable, not fitted for positions requiring independent judgment or resourcefulness. 16
Sapara Willams, also a Nigerian, in a more scathing language, observed in a Legislative Council debate that education had brought to many young men"discontent, suspicion and bitterness, indiscipline, vanity and lack of integrity". ${ }^{17}$ To get a glimpse of the mind of the authorities on the issue, we only need to listen to the man at the helm himself - Lord Lugard. Not hiding his contempt for the educated native, he said:

I am somewhat baffled as to how to get in touch with the educated native... I am not in sympathy with him. His loud and arrogant conceit is distasteful to me, his lack of natural dignity and courtesy antagonize me. ${ }^{18}$

The education introduced in Southern Nigeria was perceived to be a hand-maid and chief instrument of the missionaries in their business of prosetytization. It was also seen as irrevocably linked to Christianity, and by extension, a harbinger of European behaviour and culture. Apart from the fact that Lord Lugard had on becoming High Commissioner of the Protectorate of Northern Nigeria on 1 January 1900, agreed to maintain, on behalf of Queen Victoria, all pledges and understanding which had been assumed by the Royal Niger Company, including its policy of not supporting Christian mission in the Muslim North, ${ }^{19}$ made a decision not to replicate the southern scenario in the North as far as the education issue was concerned.

In the South, the literate and semi - literate elements had the penchant of leaving their villages in search of jobs in the emerging towns and urban centers. Social and tribal disintegration, and the weakening of ethnic and clan authority were the natural consequences. On the other hand, and to the contrary, Islam does not demand race suicide of the Nigerian as an accompaniment of conversion. It does not stipulate revolutionary changes in social life; nor does it undermine family or communal authority. ${ }^{20}$ Contrary to the fore-going also, it became apparent that Christian education bred disrespect for native rule and institutions, and therefore undermined the system of rule through native chiefs - indirect rule.

The education that was introduced to Northern Nigeria was such that was not to disrupt the system of indirect rule. It was to be used to reinforce the position of the Emir, the structure of the 
administration and to channel the course of change. The government not only started schools, but ensured that missionaries were prohibited from going into the Muslim core North, as well as see to it that efforts were concentrated in educating the Emirs sons and his kinsmen. In addition, the overall design of curbing the rapid acculturation of Northern Nigeria to Western modes was enhanced by the rather limited contact between the North and the South, and also, between the British officers and the Fulani aristocracy on the one hand, and the Westernized Southerners on the other. This position was affirmed by a Governor of Northern Nigeria, Sir H Hesketh Bell in the following words:

So far, the fundamental principles of our administration in Northern Nigeria have rested on the policy of guiding and improving native rule in such a manner as to interfere as little as possible with the traditions and customs of the people ${ }^{21}$. The commentator continued, "we do not want to replace a patriarchal and venerable system of the government by a discontented and irresponsible democracy of semi-education politicians". The education that produced this set of people as referred to above in Southern Nigeria was deplored, and had to be avoided in Northern Nigeria.

We hope, if possible, to prevent in Northern Nigeria some of the evils that have been brought about in other parts of Africa, by an over- hasty adoption of European methods and customs and there seems no reason why, under proper direction, the rulers and the people, while retaining manners, customs and traditions which have been theirs for centuries, should not gradually assimilate ideas of enlightenment, probity and humanity which will in no way be inconsistent with the patriarchial form of government which is racy to their soil ${ }^{22}$

The formal education which was to be subsequently introduced to Northern Nigeria was to achieve the above aims.

\section{Formal Education in Northern Nigeria: 1900 - 1909.}

The evolution of official policy regarding education in Northern Nigeria can be divided into three distinct periods: $1900-1909 ; 1910-1929$, and the period from the 1930s. The first period $1900-1909$ was characterized by almost total inactivity. This, according to J.S. Coleman, was due in part to Lugard's attitude towards education, and in part, to lack of funds. ${ }^{23}$ At the end of this period, Lugard announced his educational scheme to include four types of schools : (1) schools to train the Mallamai ${ }^{24}$ as clerks to replace Southerners, and as teachers in Primary Schools ; (2) schools to instruct the sons of chiefs, (3) Schools to teach the masses primary education in vernacular, and (4) cantonment schools to educate the children of Southern clerks who as Christians were to be isolated from Northerners. ${ }^{25}$

During the second period, 1910 - 1929, a carefully controlled government - sponsored educational system was established. It was however, not modeled after that which was operational in Southern Nigeria, but that of Anglo - Egyptian Sudan. ${ }^{26}$ An educational departmental was established which saw to the opening of the following types of schools - elementary schools emphasizing health, native arts, gardening, and character training; taught by northern mallamai in the vernacular, primary schools for the mallamai, which employed English Language at the upper levels; arts and crafts schools for training in indigenous handcrafts and for instructions in carpentry, metal and leatherwork, and motor repairs; and then the Katsina Teacher Training College, which was opened in $1921 .{ }^{27}$ Scrupulous effort was made by the British Colonial officials to ensure that the schools did not disrupt the existing social system.

As the schools were constructed and maintained by the Native Authorities, the emirs had not only proprietary interest in them, but nominated their students. Religion and Arabic were prominent subjects in their curriculum. In all social norms of dress, behaviour, traditional forms of salutation and such like, students were required to conform to local customs. The educational system was tailored to adapt to the environment, and to avoid a repetition of the "southern mistake".

The merger of the Northern and Southern educational department into a central department in 1930 marked the third period of educational development in the north. This period saw the elevation of Katsina Teacher Training College into a full secondary school and its transfer to Kaduna. An original plan to develop 
the Katsina College into a University College along the lines of Yaba Higher College, was later abandoned, thereby compelling Northerners to go South for training as medical technicians, pharmacists, and engineering assistants.

It may perhaps be necessary to throw some light into the reasons behind the type of education that was introduced /allowed in the north. As we indicated earlier, the major reason was to ensure that the indigenous class structure of society was not to be affected, opportunities for learning English was to be curtailed, the language of instruction was to be Hausa, and the educated few were to become a part of the administration structure. There was no intention of taking the masses out of what Grace Alele Williams calls "their normal grooves". ${ }^{28}$

As we once again made reference to earlier, education in the North targeted four different classes of pupils. (a) Mallams Viz natives educated according to native standards in Arabic and Muhammedian law. (b) sons of chiefs to be taught as boarders in a school or college established for that purpose where they would receive a primary education and be brought up in an atmosphere of loyalty to the king (c) general primary schools for children on secular basis, and (d) cantonment schools for the education of the children of native clerks (Christian and non-Northern) government officials. ${ }^{29}$

The schools for the sons of Chiefs and Emirs were to be the colonial equivalent of Eton, and the emphasis was on sports, correct demeanour, and good behaviour. The syllabus included horse-riding, polo, religious and moral instruction, reading, writing, arithmetic, drawing, geography, general knowledge and hygiene. The first school established in the North was sited in Nassarawa, within Kano Province. The site was carefully chosen as to be within easy reach of the residency, but removed from the undesirable influence of soldiers, servants, carriers and their followers who usually surround a European station. It was also within close touch with the Emir and the best of native life, but outside the town, away from temptations which a market and large city like Kano will inevitably offer. ${ }^{30}$

The various provincial administrations provided the greater part of the running costs of the schools, and took great interest in them. The Emir of Kano in whose Emirate the nucleus of education for the north stood was credited with tremendous support, financial and otherwise, for the schools. The administration planned that the school established at Nassarawa will train teachers to be released under British Education officers to start new schools in other provincial centers. Such schools were to provide education for boys who had attended the Koranic schools. By 1911, Nassarawa registered 97 sons of Chiefs, 80 Mallams. Two additional schools were established at Sokoto and Katsina in 1913. The following year saw schools founded at Zaria, Bida, Ilorin and still another in Kano.

Missions were not permitted to establish schools in the Muslem areas, for reasons already stated. But the Church Missionary Society (CMS) had established a station in Zaria around 1900. The missions appeared more concerned with medical rather than education work in the Muslem areas of the North. However, even with a late start in 1909, and without support from the administration, the enrolment in mission schools in 1913 was greater than that in the administration schools. ${ }^{31}$ Like the native administration, the missions started their main schools in the larger centres of population. They however spread less rapidly in the South even more rapidly than the native Administration schools in the north.

It may be necessary to consider the fate of secondary education in the north. In much the same way as the school at Kano was the nucleus of elementary education in the north, a nucleus of secondary school work was established in Kasina in $1922 .{ }^{32}$ It started with Katsina College which was established as a Teacher-Training institution, rather than a secondary Grammar School. Its growth was slow but steady. Four years after its establishment, it had an enrolment of not more than 56 students. In spite of this, it provided the native teaching personnel for the government primary schools, as well as the new government post primary or middle schools unlike the administration schools. Teaching, at this level was done in English. To cater for the need for mechanics and lower- grade technicians, industrial craft schools were established at Sokoto and at Bauchi by 1919. The industrial schools had an enrolment of 157. ${ }^{33}$

Perhaps we may at this juncture state, that formal education in the North was a recent phenomenon as compared to the South. As early as 1842 , certain areas of the South, especially the South West, had thriving schools. The emphasis in the North was reading in 
Hausa. As such, no external examinations were introduced, and reading materials were carefully chosen and translated to indigenous languages for a select few of future Emirs or civil servants. English was only introduced at the highest level and for yet a select few. Both missionary and government schools were made to maintain this policy. All these were the exact opposite of the situation in the South.

To a large extent, these disparities in north and south, on the education front were traceable to the mind-set of the administration. For instance, Lord Lugard was of the view that the character (that is) the principles and standards which guide and control thought and actions, and involve the exercise of self - control and discipline, were the hallmarks of education. He went on to pontificate that: the second most important function of education is to adapt the individual to his environment ${ }^{34}$

The craft schools or what was erroneously referred to as "industrial schools", established for the masses were ostensibly made to meet this condition. It is evident thus far that a major characteristic of the spread of education in the North was its limited and directed growth by the administration. Quality rather than quantity appeared to be the major concern of the administration. As Lugard once again emphasized, the primary object of all schools should be the formation of character and habits of discipline, rather than the mere acquisition of a certain amount of book learning or technical skill. ${ }^{35}$

What this meant in practice was that teaching was to be strictly monitored to ensure that pupils did not receive any education that will make them unfit for their normal position in life. To this end, the teaching of English was severely curtailed, as we have seen, while new skills that would have caused the recipients to be qualified for work in the commercial houses were also not encouraged. The sons of peasants that had any opportunity to attend schools were restricted to the craft schools, the so - called industrial schools. They consequently learned nothing new to attract them away from their normal pattern of life. Thus the social status of the student or pupil determined the type of education that he was allowed to obtain. We therefore find that education really became a means of separating the indigenous ruling class from its subjects, and therefore, a means of bolstering indirect rule in the north.
While we may reach the conclusion that in retrospect, the system that trained the ruling classes so that they could in turn train their own subjects was simply obscurantist, as future interaction between north and south will show. Besides, no mention has been made of women education so far in our analysis. We shall therefore proceed to say few words on that to get a wholistic view of education in the Islamic society of Northern Nigeria of the early periods, before we proceed to consider in contrast what the situation was in Southern Nigeria.

\section{Women Education in Northern Nigeria}

It is axiomatic that women education is not provided for in the accepted beliefs in Islam. As we saw in our discussion on the Koranic school system or almajiri schools, only boys were the pupils of the Mallams. In general terms, it is evident that Western education in the North has always been characterized by differential access with regards to sex and class. In terms of sex, it was generally marked by limited access for women at all levels. ${ }^{36}$

This appeared to reflect a convergence of British colonial interest and ideology and those of the Northern aristocracy in the pre - independent period. There is evidence to support the assertion that Britishdesigned education permitted girls to leave school "at the customary age of marriage" 37 . The so-called 'marriage age' ranged from ten in Sokoto, to twelve, thirteen or fourteen in many other Northern States. This of course, placed early terminus to the education of girls in the north. From the pre-colonial, colonial and even upto the post-colonial period, the Nigerian state has never been neutral on the issue of women education. It has tended to support continued control over women through marriage. This is observed through its failure to enforce sanctions forbidding the unauthorized removal of girls from school or to set a minimum age for marriage.

According to Marg Csapo, in northern Nigeria, women are considered second class citizens. As such, their education does not receive the priority as that of boys ${ }^{38}$. Parents are reluctant to send girls to school and those who manage to attend school are often withdrawn before they complete any school programme. Certain factors have been identified as responsible for bestowing this second-class citizenship on girls in the north, and for impeding 
their full participation in educational programmes such as the free Universal Primary Education scheme.

According to A. Haroun, these include religious, social and economic reasons and factors. ${ }^{39} \mathrm{He}$ itemizes the factors as follows:

1. Traditional antagonism of Moslems towards Western education.

2. Marriage customs and seclusion of women, purdah (Kulle) in the Hausa Muslim Society

3. Fear of moral laxity

4. Paucity of post - primary institutions

5. Lukewarm support by political leadership

6. Parental misconception of the Islamic view on the education of women,

7. The place of women in Muslim society. ${ }^{40}$

These factors are briefly analyzed to highlight their significance in impeding women education in the north.

\section{Antagonism to Western Education}

It has been indicated that Islam predated Christianity in Nigeria by over 300 years. ${ }^{41}$ While trade links with North Africa and Western Sudan spread Islam all across Hausaland, Christian Missionaries that came to Nigeria in 1840's were responsible for converting pagans and Muslims to christianity. Consequent upon this, schools and Western education became synonymous with Christianity. Muslims became wary of the fact that if they send their children to mission schools they will return as Christians. As a result of this, Muslims insisted on sending their children only to Quaranic schools. Initially, this Quaranic schools had only boys in attendance. It was only in the 1930's that Quaranic schools for girls were established, but in designated places - Kano, Katsina, Sokoto, Birni Kebbi and Argungu. ${ }^{42}$

Apart from the situation highlighted above, recent surveys have shown the prevalence of parental resistance to Western education for their daughters in the north. Parents did not wish their daughters to mix with sons of non-muslims in schools. Besides, muslim parents questioned the value of Western education, since they viewed it as a destructive force to traditional Hausa way of life. Again, since they considered missionary schools to be occupation oriented, the occupation of girls was to get married, there was therefore no need for their schooling.
Western education was thus looked upon as a subversive force against parental authority and control, and Hausa - Muslim traditions.

\section{Marriage Customs and Seclusion of Women}

Age limits may not have been fixed for marriage in Islam. But legally, according to R. Levy, young children may marry. ${ }^{43}$ In most of Hausaland or northern Nigeria, child marriage is the rule rather than the exception Girls are married at the of 12 , and often at younger ages of five or six to be brought up by their husbands. When girls are married off at such a young age, their chances of receiving education are effectively mortgaged, if not completely forestalled. To make matters worse, after marriage, in most Muslim families, the girl is subjected to purdah seclusion of wives indoors. This is to protect her from meeting other men. It is also on a doctrine that Islam commands that women should be secluded and not exposed to the opposite sex. Generally, parents expressed strong fears that a girl might refuse to get married because of her education. In their view, education should result in obedience to parents and husbands. ${ }^{44}$ If girls learned to rebel against their parents and society, then there was no reason for sending them to school.

\section{Place of Women In Islam.}

"Men stand superior to women in that God hath preferred the one over the other". ${ }^{45}$ This injunction quoted prom verse 38 of chapter 4 of the Quar'an is a testimony to the place of women in Islam. This verse has further been interpreted to mean that men are superior in mental ability and good counsel, in their ability to perform duties and to carry out divine commands. It is their role to become prophets, religious leaders, saints, go to pilgrimages, testify in courts, worship in the mosque on fridays, elect chiefs, go to holy wars, inherit a larger share and obtain a divorce easily. ${ }^{46}$ According to M. Taiwo:

It will be virulent and derogatory on the part of anyone bridled by Western culture, or a feminist to convince that all believing women should be given full emancipation, to allow intermingling of sexes, since their efforts and faith are not equal and will not also be recompensed equally by God. 


\section{Fear of Moral Laxity in the Schools}

It is generally believed that educated women are associated with low morals. According to L.Gaya, the higher the education, the lower the morals. ${ }^{47}$ Parents believe that Western education will open the girls mind to the evils and vices of modern civilization.

\section{Misconception of the Islamic View on the Education of Women}

There is a prevalent parental misconception that education for girls is unIslamic. There is a perception that parents who sent their daughters to school were regarded as having abused the Islamic faith. This is because girls were expected to learn only their religion, and to marry. It was against such misconception that Alhaji Sir Abakakar II Sultan of Sokoto in his opening address in support of the UPE in 1976 admonished Musliam parents on the call of prophet Muhammed that everybody should seek knowledge and education, even if it takes one to China. In the same vein, Fafunwa pointed out that following the Jihad of 1804, Shehu Uthman Damfodio encouraged outstanding reforms in Hausa - Muslim society including the education of women. ${ }^{48}$ Despite these admonitions, certain Muslim sects in Nigeria still believe that women education is unIslamic.Chibok Girls' Saga. While there may yet be other factors to be considered regarding mitigating issues of female education in the north, we are persuaded that those mentioned above have given a general perception of the trend to afford an appreciation of the situation. We shall now proceed to look at the scenario in Southern Nigeria to enable a wholistic grasp of educational development nationally.

\section{Educational Development in Southern Nigeria, 1842 - 2015.}

We do not intend to expend much intellectual capital on this because educational development in Southern Nigeria can be conceived as simply the opposite of the situation in Northern Nigeria that we have considered. We shall therefore proceed to highlight some salient features that determined the unique characteristics of the south.

As we noted, Western education in Nigeria is intricately intertwined with christian missionary enterprise. The first time Europeans came in contact with people of what later became Southern Nigeria was in 1472, when Portuguese merchants visited Lagos and Benin. ${ }^{49}$ Following this, spasmodic missionary activities started in Benin in 1515, when some Catholic Missionaries set up a school in the Oba's palace for his sons and sons of his chiefs who had been converted to Christianity. But this early attempt at proselytization and establishment of school by the Portuguese was almost totally wiped out by the ravages of the slave trade.

These were not revived until the 1840's through what Fafunwa called "second missionary endeavour". This was marked by the advent of the first English speaking Christian mission in Badagry in September 1842. This had been preceded by the famous Niger Expedition which had been sent out in 1841. Though disastrous in its outcome, but it was this expedition that opened the hinterland of southern Nigeria to Christian missionary enterprise and a subsequent educational in-road.

The idea of evangelizing Nigeria originated from the Church Missionary Society, but it was the Methodists who first sent missionaries to Badagry. The Methodists are credited with establishing the first school in Nigeria, but the C.M.S mission was to make the most important contribution to education in the early period. While the Methodists and the C.M.S were consolidating their missionary activities in and around Badagry and Abaokuta, the Church of Scotland Mission otherwise called the Presbyterians, sent an exploratory mission to Calabar in 1846. The group was led by the Rev. Hope Masterton Waddell. The Catholics were not be left out in what Fafunwa has called "spiritual scramble" 50 for Nigeria. In 1868, they made their advent into the Nigerian missionary field. From the mid to the late $19^{\text {th }}$ century, the various missions had established in Southern Nigeria. They included the Methodists, the C.M.S otherwise called the Anglicans, the Baptists, the Roman Catholics. Others included the Church of Scotland Mission or Presbyterians, the Qua Ibo of Northern Ireland, the Primitive Methodist and the Basel Mission.

As we noted earlier, the primary objective of the early Christian missionaries was to convert the heathen or benighted African to Christianity through education. Thus the early missionary school in Nigeria was an adjunct of the church. Unlike the situation in the North, as we had seen, the early missionaries in the south knew no local language, so the medium of 
instruction in the schools was English. We note that even the parents encouraged the use of English, as the wanted their children to learn the language of "commerce, civilization and Christianity." Irrespective of whatever weaknesses, the early christian schools were seen by both parents and students as a means of social emancipation and mobility, and as such an avenue for economic advancement or improvement. School leavers who had completed their courses either stayed on with the mission as catechists or lay workers of the church, or became teachers, clerks, priests and the like.

The period 1842-1929 has been conceived as marking the beginning of modern education in Nigeria. To be more precise, the period between 1842 and 1914 saw discernible educational development in Southern Nigeria. This period was marked by intensive missionary activity and expansion. Within this period also, and precisely, up to 1882 , the colonial government paid little or no attention to the educational needs of the people. It has therefore been termed an "era of exclusive Christian missionary education in Southern Nigeria" 51

In addition to some vocational training, such as agriculture, carpentry, bricklaying, grinnery etc, this period also saw the missions setting the moral tone for their members. The schools became avenues for character-training, a stern code of European ethics and such likes. The missionaries hoped to produce a group of people who were Nigerian in blood only, but European in religion, thought and habit. The students themselves tended to accord with the preferences of the missions. They tended to shun the culture of their people. They preferred the music, dress, habits, food, and arts of the Western world.

This was largely the situation in southern Nigeria until 1882 when the first Education Ordinance was promulgated for the Colony of Lagos, which was still being jointly administered with the Gold Coast colony. The ordinance covered the West African territories of Lagos, the Gold Coast, Sierra Leone and the Gambia. This marked the beginning of government intervention and interest in the education of the people it was either ruling or protecting. The separation of Lagos from the Gold Coast in 1886 necessitated the enactment of the first purely Nigerian education ordinance in 1887. Following this, the Christian missions continued to open more schools with the full support of the colonial government.
The scenario created the phenomenon of Assisted and Unassisted schools. The first Government Secondary School - Kings' College was founded in Lagos in 1909. This was against the background to the first Grammar School in Nigeria, established by the C.M.S, C.M.S Grammar Schools, in Lagos in 1859. Table I and II show assisted and unassisted schools, and Mission and Government established schools in Southern Nigeria of the early period, respectively.

\section{Table I: Assisted and Unassisted Schools}

\begin{tabular}{|l|l|l|}
\hline Angency & Name of Institution & Location \\
\hline Government & Assisted Schools & Lagos \\
\hline $\begin{array}{l}\text { Anglican } \\
\text { (CMS) }\end{array}$ & $\begin{array}{l}\text { CMS Grammar } \\
\text { school }\end{array}$ & Lagos \\
\hline $\begin{array}{l}\text { Anglican } \\
\text { (CMS) }\end{array}$ & CMS Girls Seminary & Lagos \\
\hline Catholic & $\begin{array}{l}\text { St. Gregory } \\
\text { Grammar School }\end{array}$ & Lagos \\
\hline Catholic & St. Mary's Convent & Lagos \\
\hline $\begin{array}{l}\text { Anglican } \\
\text { (CMS) }\end{array}$ & $\begin{array}{l}\text { Anassisted schools } \\
\text { School }\end{array}$ & Abeokuta \\
\hline $\begin{array}{l}\text { Church } \\
\text { Scotland }\end{array}$ & $\begin{array}{l}\text { Hope Waddle } \\
\text { Institute }\end{array}$ & Calabar \\
\hline Methodist & Boys High School & Lagos \\
\hline Methodist & Girls High School & Lagos \\
\hline African & $\begin{array}{l}\text { Eko Boys High } \\
\text { School }\end{array}$ & Lagos \\
\hline
\end{tabular}

Source: Fafunwa p. 99 
Table II: Mission and Government Established Schools in Southern Nigeria

\begin{tabular}{|c|c|c|c|}
\hline Angency & School & Location & $\begin{array}{l}\text { Fou } \\
\text { ndin } \\
\text { g } \\
\text { date }\end{array}$ \\
\hline CMS & $\begin{array}{l}\text { CMS Grammar } \\
\text { School }\end{array}$ & Lagos & 1859 \\
\hline RCM & $\begin{array}{l}\text { St. Gregory's } \\
\text { College }\end{array}$ & Lagos & 1876 \\
\hline Methodist & $\begin{array}{c}\text { Methodist } \\
\text { Boys' High Sch. }\end{array}$ & Lagos & 1878 \\
\hline Methodist & $\begin{array}{c}\text { Methodist } \\
\text { Girls' High Sch }\end{array}$ & Lagos & 1879 \\
\hline Baptist & $\begin{array}{c}\text { Baptist Boys' } \\
\text { High School } \\
\end{array}$ & Lagos & 1885 \\
\hline $\begin{array}{l}\text { Church of } \\
\text { Scotland }\end{array}$ & $\begin{array}{l}\text { Hope Waddle } \\
\text { Institue }\end{array}$ & Calabar & 1895 \\
\hline CMS & $\begin{array}{c}\text { Abeokuta } \\
\text { Grammar Sch. }\end{array}$ & Abeokuta & 1809 \\
\hline Government & Kings College & Lagos & 1809 \\
\hline $\begin{array}{c}\text { Private } \\
\text { African } \\
\text { initiative }\end{array}$ & $\begin{array}{c}\text { Eko Boys High } \\
\text { School }\end{array}$ & Lagos & 1913 \\
\hline CMS & $\begin{array}{c}\text { Ibadan } \\
\text { Grammar } \\
\text { School } \\
\end{array}$ & Ibadan & 1913 \\
\hline CMS & $\begin{array}{c}\text { Ijebu Ode } \\
\text { Grammar Sch. }\end{array}$ & Ijebu Ode & 1913 \\
\hline RCM & $\begin{array}{c}\text { St. Mary’s } \\
\text { Convent }\end{array}$ & Lagos & 1913 \\
\hline
\end{tabular}

Source: Fafunwa, p. 101

Most of these schools of the early period were largely residential, i.e. boarding. The missions and the government felt that if children were to develop along civilized lines, their daily life must be supervised, controlled and directed along proper lines. That is to say, if a 'raw' African is to be made into a civilized, Christian, black European, he must be isolated from the evil influence of his pagan past and present. ${ }^{52} \mathrm{It}$ was however this so - called 'Civilized, Christian, black European that eventually became an irritant to Colonial European officialdom. According to Lord Lugard, education in Southern Nigeria seems to have produced discontent, impatience of any control, and an unjustifiable assumption of self - importance in the individual. ${ }^{53}$ On the whole, Lugard appeared to harbour a deep personal animosity against the educated Nigerian.
He subsequently translated this personal animosity into a policy position. On assumption of office as Governor General $^{54}$ of Nigeria following the amalgamation of 1914 , he proceeded to personally supervise the organization and administration of education in Nigeria. He thereafter declared:

It is the cardinal principle of British Colonial Policy that the interest of a large native population shall not be subjected to the will either of a small European class or of a small minority of educated and Europeanized natives who have nothing in common with them, and whose interests are often opposed to theirs. ${ }^{55}$

It was this policy that accounted for Lugard's educational policy of separating and maintaining the class structure of society in Northern Nigeria. It also equally informed the restriction of missionaries into Muslim areas of Northern Nigeria, and quarantining Northern Nigeria from the contagion of Southern radicalism of the educated class. Much of the imbalance which has generated a lot of headache to statecraft in modern Nigeria is traceable more or less to this situation. Before we come to this, let us consider what institutions that the modern education system has created, and how they have aided or stymied national development.

\section{Educational Institutions and National Development in Nigeria}

Our concern here is not the educational institutions in the form of schools, colleges and universities. We are concerned with such socioinstitutions that were deliberately or inadvertently created in the process of advancing the educational system of the country. Such institutions range from the Almajiri to such administratively-created institutions as the Joint Admissions and Matriculation Board (JAMB), the National Universities Commission (NUC), the Universal Primary Education (UPE), the Universal Basic Education (UBE) Scheme etc.

\section{The Almajiri Institution}

The Almajiri system of learning is conceived in diverse ways: an institution, a system of education, an educational programme ${ }^{56}$ etc. In spite of this 
diversities in conceptualization, or rather because of it, it is evident that the system has become so entrenched that it has become equally institutionalized. Some commentators have indicated that it was colonialism that distorted the original form and content of the Almajiri system ${ }^{57}$. According to them, the distortion started in 1904, when the British invaded and colonized Northern Nigeria.

\begin{abstract}
"They killed and disposed (sic) those emirs who resisted the foreign rule, while those who were subjugated lost control of territories and accepted their new roles as mere traditional rulers used only for the indirect rule. The British also refused to recognize the Almajiri education system as an important education system and deliberately abolished its state funding arguing that they (sic) were mere religious schools. Boko, meaning Western education was introduced and funded instead. ${ }^{58}$
\end{abstract}

This may have been true of what happened. But what it means is that since 1904, the Almajiri Institution as we know it has been running. It is indicated that what goes, for an almajiri school is a spot where the almajiri converge to study the Quar'an. That place is called Islamiyya. A typical Islamiyya is devoid of any formal educational curriculum. The life of almajiri consist of memorizing the Quar'ran. This is called 'tilawa'. The everyday life of an almajiri starts as early as 6.00am, when he is sent out to the streets to scavenge for food or beg for alms, a practice that is called 'molah'. He begs in all manner of places motor parks, street corners, restaurants, washes plates at the restaurants, and other menial jobs. He is expected to remit more than half of his day's income to his Mallam.

A commentator has informed us that a typical almajiri boarding school consists of the mallam and his assistant with an average of 40 to 100 students crammed in a small space room as an hostel without mattrassess or bedding. The process of teaching the almajiri is also very harsh. They are horse-whipped for every little mistake and often deployed to do hard and odd jobs for their teachers - Mallams. The students are made to believe that English language or western education (Makaranta Allo) is a nuisance or sinful. They are also taught mobid hatred for non- believers (infidels) ${ }^{59}$ Christians and Westerners alike. Almajiri education takes around twenty years to be completed. Thus, by the time an almajiri graduates he is already too old for formal/western education, and so cannot fit in the formal sector. Therefore he becomes a danger to everybody, but his kind. He looks at everybody, especially the westerner or products of western education, non- Muslims, Christians and other ethnics with hatred and suspicion. Without a trade or vocation or skill of any useful sort, the only service he can be called upon to engage in is jihad or sectarian violence or other forms of criminality.

Conservative estimate of the number of almajiris in Nigeria vary between 7 and 9 million. $^{60}$ When an educational system throw up this number of people who are not only useless in the formal sector of the economy, but are indeed a danger to the society, then the developmental trajectory of such a society is unconscionably jeopardized. Efforts have never been spared by the government to try and overcome the constrains of the Almajiri and Koranic education systems on the educational and other aspects of development in Nigeria. These efforts come by way of such schemes as the Universal Primary Education.

\section{UPE and Universal Basic Education (UBE) Schemes}

The UPE scheme was billed to take off from September 1975, but for undisclosed administrative reasons, its stake-off date was shifted a year later to September 1976. By reason of the UPE all primary schooling became free of charge. By 1981, it was envisaged that all six year old children will be in school. In other words the UPE was expected to sound the death - knell to the Alamajiri system by depriving of it of most of its patronizers - children from poor background. Almost forty years after, we still see almajiri in their millions on the streets of Northern Nigeria. A heart - rending picture of the almajiri is created by a commentator in a $21^{\text {st }}$ century Nigeria:

These boys swam into the society with no bearing moving from street to street, house to house, vehicle to vehicle. They were everywhere; markets, car parks, restaurants, university, gates, name it. They became a burden as well as nuisance to the society. 
They sang, begged and prayed, appealing to the mercy and good will of the people. Its really sad when you see these Almajiris, hungry, malnourished, wounded; rushing for flies' in fested left over food, searching through trash can for little morsels, just to stay alive. They consume all kinds of food, fresh or stale. Their common food called "jagala" which is stored by an almajiri over a number of days is a combination of locally made corn food (tuwo), pasta and boiled yam altogether in one bowl like a fresh vomit. They roam about dirty, tattered, bare feet, pale with flies' pircering on their cracked lips and dry faces, which is filled with rashes or ringworm. They sleep on worm - out mat in uncompleted building. Goats may not find the small rooms where the almajiri and 15 others sleep conducive as there are no windows for cross-ventilation and the walls have given room to cracks looking as if it will fall the next minute ${ }^{61}$

We have quoted this commentator this long to give the reader a mental picture of who the almajiri really is. When a society harbours millions of these pitiable and totally disgusting species of mankind in its midst, it is left to the imagination to decipher what kind of development such a society could hope to see. When a society condones this, just so that the victim is not exposed to the education that might cause him to embrace Western ways that is likely to make him a real human person, that society has no reason to dream of development. Yet that society is $21^{\text {st }}$ century Nigeria.

This mindset has equally been responsible for the limited or non - achievement of the aims of such mass educational projects/ programes as the Universal Basic Education Act, the Child Right Act (CRA), the Convention on the Right of the Child and other such international protocols that seek to protect children from exploitation and abuse in the mould of the Almajiri Institution.

The Universal Basic Education Act provides for the right of children to basic education. Section $1-20$ of the Child Right Act (CRA) cover diverse aspects of childrens' welfare and development, including their right to survival and development, freedom from discrimination, freedom of thought, concience, and religion, and freedom from harmful social and cultural practices, separation from parents, child abuse, and torture. It further imposes the responsibility upon the State to ensure that children receive and enjoy their right to education, health services, and family protection. ${ }^{62}$ The Convention on the Right of the Child (CRC) on its own, recognizes, among other things, the need for children to grow up in a family environment where they may find love, happiness, and an environment conducive to their harmonious development.

Other instruments recognizing the dignity of children, as well as their right to develop within the parameters of human dignity include the Geneva Declaration of the Right of the Child, 1924, the Declaration of the Right of the Child adopted by the UN General Assemble on 20 Nov. 1959, the Universal Declaration of Human Right, the International Covenant on Civil and Political Rights, (articles $23 \& 24$ ) and the International Convenant on Economic, Social and Cultural Rights (article 10). There is also, of course, the African Charter on the Rights and Welfare of the Child. $^{63}$

We must not forget the Current United Nations Development Goals (MDGs). According to Salim Magashi, its goals 1, 2, 4 and 7 encapsulate important policy bearing directly on the Almajiri System in Nigeria. For instance, Goal I seeks to eradicate extreme poverty and hunger, while goal 2 seeks to ensure universal primary education for all. Goals 4 and 7 seek to reduce child mortality and ensure environmental sustainability, respectively. ${ }^{64}$ The Almajiri system as practiced today in Nigeria exposes children to extreme hunger and lays the foundation of a life of perpetual poverty, as the almajiri did not have opportunities to pursue a dignified life or get educated in line with modern realities.

It has been observed that most states in Northern Nigeria, where Muslims are the majority have been unwilling to domestic the Child Rights Act (CRA), ${ }^{65}$ and other international instruments bearing on the rights of the child as indicated above. This is seen to be in deference to the almajiri institution. The question remains, how can this differential education system in the country foster development? Without denying one's right to his religious inclination, Nigerians must decide either to be part of the modern world and develop alongside its preferred pattern or 
reject its basic tenets and be condemned to self immolation.

We proceed to briefly consider the place of such bodies and institutions as the National Universities Commission (NUC) and the Joint Admissions and Matriculation Board (JAMB) in both educational and national development in Nigeria. The federal government is the sole authority in Nigeria vested with the powers to determine policy objective for universities, and to set up agencies for implementing measures for achieving them.

The NUC and JAMB appear to be about the two most prominent of the implementation agencies. The NUC was first set up in 1962 to coordinate university development in the country. Between 1962 and 1975, it was unable to satisfactorily discharge its duties. This, according to A.A. Ali was because higher education remained a joint responsibility of both regional (states) and federal government. ${ }^{66}$ But from 1975, when higher education became the exclusive responsibility of the federal government, the NUC began to assume a greater role in the administration of universities. When in 1979, the responsibility for higher education was once again reversed as joint, the NUC was still changed with enforcing Federal Government Policy measures in universities, allocating financial support, and ensuring uniform standards. One of the cardinal instruments in the arsenal of the NUC in ensuring minimum standards is the periodic accreditation of degree programmes in the universities.

Alongside the NUC, JAMB was another agency set up to help stream-line university education in Nigeria. Established in 1977 on the recommendation of the Committee of Vice-Chancellors of Nigerian Universities, its main function was to streamline university admissions and entrance. This was to eliminate the problem of multiple admissions. More importantly, it was conceived as "a device for ensuring that each university was a microcosm of the country in terms of admission and ethnic compostion." $" 67$

To What extent have these agencies met their set objectives in terms fostering educational development and other nation-building imperatives of the country over the years? This can only be discerned against the background of the identified objectives of university education in Nigeria. The earliest articulation of such objectives was made by the Asquint and Eliot Commissions. As indicated by N. Okafor, the Asquith and Elliot Commissions saw the necessity for manpower as the impelling motive of the British colonial administration in attempting to found institutions of higher learning in West Africa. ${ }^{63}$ As to the functions of universities as seen from the Aquith and Elliot Commissions, Ali elaborates:

To produce graduates with leadership qualities which surface required. To produce professional men and women to take over senior appointments in health and adminiseration and other self-rule from expatriates. To serve as a platform for producing true nationalists who would form political institutions with national character. To refine and maintain the best in our local traditions and cultures and yet be capable of holding their own intellectually on the international scene. ${ }^{69}$

The Ashby Commission and Harbibson's High Level Manpower Study for Nigeria also emphasized manpower development for Nigeria. But by the end of the second decade of Nigeria's independence, the education policy objectives still emphasized manpower development even though new emphasis also came to be placed on issues of science and technology. Additionally, issues of social justice, equity, national unity and integration also began to come into prominence. We thus observe that the first stated objective of the educational programme of the Third National Development Plan 1975 - 80 was: to expand facilities for education aimed at equalizing individual access to education throughout the country. ${ }^{70}$ Introducing yet additional role for the universities, the Implementation Committee on the National Policy on Education, 1978 advocated that measures to be adopted for the achievement of national unity through the universities. It therefore recommended that each university should recruit students from every part of the country. ${ }^{71}$

Restricting ourselves to this last recommendation, we may wish to assess the effectiveness of the NUC and JAMB in achieving those desired objectives of educational development and nation-building. Of all the measures designed to facilitate the achievement of the objective of national unity, the expansion of universities to all parts of the country appears to be 
the most thoroughly implemented. From 1978, when the measure was recommended to 1990, 16 new universities were established, 8 apiece by States and the Federal Government. As at the moment, there are about 40 Federal universities, in addition to about 44 and 69 state and private universities, respectively in Nigeria. $^{72}$ It is believed that this situation going forward will make higher educational opportunities more accessible to all, reduce ethnic tension and generate a sense of contentment and belonging in the Nigerian. A closer look may reveal that this may not necessarily be the case.

It is common practice for the indigenous people of a state or locality where a university is located to regard it as their own institution. It was on this premise that Okwudiba Nnoli argued that the conflict over the headship of Lagos University in the 1960's could be directly attributed to the assertion of ethnic interest by those indigenous to the area of its location. ${ }^{73}$ The situation does not appear to have witnessed any significant change since then.

We also observe that universities recruit most of their students from their immediate geo-political and cultural environments. Besides, there exists a clear distinction in the pattern of student recruitment between the Northern and Southern universities. The percentage of Northern students enrolled in Southern universities has remained extremely low. In the East, it rarely exceeds one percent while in the West it varies from two to seven percent. To the contrary the percentage of southern students enrolled in Northern universities is quite substantial. ${ }^{74}$

Taking 1986 as a base year, we find inter-regional pattern of student enrollment in Nigerian universities to be grossly unequal. Thus whereas in any university in the west $16 \%$ of the students were Easterners, only $4 \%$ were Northerners. On the other hand, $10 \%$ of students in Eastern Universities were westerners, whereas Northerners accounted for only $1 \%$. In the same year, $16 \%$ of students in Northern universities were Westerners, while 9\% were Easterners.

\section{Table III: \% Inter-Regional Recruitment of Students 1986.}

\begin{tabular}{|l|l|l|l|}
\hline & West & East & North \\
\hline West & $43 \%$ & $10 \%$ & $16 \%$ \\
\hline East & $16 \%$ & $38 \%$ & $9 \%$ \\
\hline North & $4 \%$ & $1.0 \%$ & $42 \%$ \\
\hline
\end{tabular}

\begin{tabular}{|l|l|l|l|}
\hline Location & $36 \%$ & $50 \%$ & $32 \%$ \\
\hline Others & $1.0 \%$ & $1.0 \%$ & $1.0 \%$ \\
\hline Total & $100.0 \%$ & $100.0 \%$ & $100.0 \%$ \\
\hline
\end{tabular}

Source: Akpan, P. 301

From the above table, it can be concluded that there is generally a low interaction of students between North and South, but more interaction between North and West, than between East and North. It is also equally observed that both NUC and JAMB are handicapped meeting the requirements of the National Policy on Education in terms of fostering national unity. This is because there is hardly any strong mechanism for enforcing student recruitment ratio. The NUC only oversees, but does not interfere with the day to day administration of the universities. JAMB on the other hand conducts entrance examinations to the universities but can offer admission only with full cooperation of the respective universities. Besides, the choice of university rests with the candidate seeking admission.

\section{Concluding Remarks}

It is evident that much of problems of the educational development of the country are very much tied to the cultural diversity of the polity. Institution and policies created and adopted to engender national integration, harmony and unity and to aid nation-building in the educational sector are more or less measures taken in response to the problem of diversity. Thus to a large extent, such measures and policies are instrumentalist in conception.

More at home in explaining social relations between and among ethnic groups in multiethnic post-colonial African societies ${ }^{75}$, the instrumentalist model of social analysis is employed in the broader sense of a manipulative device by both the state and social groups to achieve set objectives. These objectives may be to protect and project received social religious prejudices, and or to ensure the subjugation of such prejudices for the achievement of broader national objective of development and nation-building.

It is these prejudices that have ensured the continued existence of Almajiri schools in $21^{\text {st }}$ century Northern Nigeria for instance. Such prejudices also insist that the so-called educational imbalance between North and South persists despite policy measures such as the UPE, UBE etc, including of course the exertions of the NUC, and JAMB, as we have seen. 
While we acknowledge the fact that changes are being made in terms of blending the almajiri system with Western educational traditions, as instances abound of graduates of Almajiri educational institutions proceeding to acquire certificates and degrees in conventional educational institutions, we do observe that the almajiri system is still alive and thriving.

This paper is of the opinion that if Nigeria must achieve the Millennium Development Goals as they pattern to the educational sector, and by so-doing, induce and sustain development in the domestic environment, conscious effort must be made to jettison some of these prejudices identified in this study.

\section{REFERENCES}

1) Grace Alele Williams, Education and Government in Northern Nigeria, Presence Africaine, Nouvelle Serie, No 87,Pre - Colloquium on "Black Civilization and Education", 1973, pp. 156 - 177, also on stable URL: Uttp://www.jstors.org/stabl/24350551, accessed: 20. $01 ; 2017$. Let us also note that except where otherwise stated. by 'education' in this analysis, we mean Western Education.

2) Williams, P. 157.

3) Hamidu Alkali, 'A Note of Arabic Teaching in Northern Nigerian; in Kano Studies, No 3, june 1967, P. 11, in A. B. Fafunwa, History of Education in Nigeria, Ibadan, NPS Edu. Pub, 1974, p. 48.

4) Fafunwa, P. 48

5) A. R. I. Doi, Introduction to the Hadith, Lagos, Islamic Publications Bureau, 1970, pp. 90 - 95.

6) Alkali, P. 10

7) See Salim Bashir Magashi, "Education and the Right to Development of the Child in Northern Nigeria: A Proposal for Reforming the Almajiri Institution", in Africa Today, 61, (3) P. 66

8) Magashi, Ibid.

9) Magashi, P 68.

10) For much of the details of almajiri educational system in Northern Nigeria, including the merits and demerits of the institution, see Magashi, cited, among other publications.

11) For an account of the administration of Northern Nigeria by the Royal Niger Company, including the challenges to that administration, see John E. Flint, Sir George Goldie and the Making of Nigeria, London, OUP, 1960, pp 34 - 155, 216 -
312; Margery Perham, Lugard: The Years of Adventure_1, 1858- 1898, London, Collins Clear Type Press, 1956, pp 495 - 557; 673 - 713.

12) Edmund D. Morel, Affairs of West Africa, London, William Heinemann, 1902, pp 258 - 59.

13) See Lord Lugard, "Instructions to Political and Other Officers on Subjects Chiefly Political and Administrative", 1906, Lagos, Government Printer, 1907, in Williams, p. 160.

14) Lord Lugard, The Dual Mandate ( $2^{\text {nd }}$ Edition), London, William Black-wood and Sons, 1923, p. 203.

15) Edmund D. Morel, Nigeria: Its People and Problems, London, Smith Elder and Co. 1911, p. 154.

16) Dr. Henry Carr, Inspector of Schools, in a Speech in 1914, in Williams, p. 164.

17) Ibid.

18) Perharm, Lugard; The Years of Authority 1898 1945, London, 1960, p. 586, in Fafunwa, p. 119.

19) See C. W. J. Orr, The Making of Northern Nigeria, London, 1911, p. 289, in Coleman, p.133. James S. Coleman, Nigeria: Background to Nationalism, Berkerley \& L. A; UCP., 1958.

20) Morel, pp. $216-17$.

21) Sir H. Hasketh Bell, "Recent Progress in Northern Nigeria", in Journal of the Royal African Society, X, July 1911, p. 392.

22) Bell, Ibid.

23) Coleman, p. 137.

24) The Hausa word Mallamai originally referred to the "learned". It however now refers to the educated class generally, and Mallam has become a title equivalent to mister in English, prefixed to the name of a man from the Muslim areas of Northern Nigeria.

25) F. D. Lugard, "Annual Reports, Northern Nigeria, 1900 - 1911”, p. 671, in Coleman, p. 137.

26) Coleman, p. 138.

27) Coleman, p. 138.

28) Williams, p. 168.

29) See Colonial Office, Report for Northern Nigeria 1905 - 1906, London, HMSO, 1907, P. 120, in Williams, p. 168.

30) Orr, pp. $267-68$.

31) See, "Colonial Office, Report for Northern Nigeria 1919”, p. 8, in Williams, p. 168.

32) Williams, p. 172.

33) "Colonial Office; Report for Nigeria 1919", London, HMSO, 1920, p. 10, in Williams, p. 172.

34) Lugard, The Dual Mandate, p. 431. 
35) Lugard, p. 431.

36) See Rene Pittin, "Marriage and Alternative Strategies; Career Patterns of Hausa Women in Katsina City", Ph.D Dissertation, SOAS, 1979, pp $437-447$.

37) J. Trevor, "Western Education and Muslim Fulani / Hausa Women in Sokoto, Northern Nigeria", in G. N. Brown and M. Hiskett (eds), in Conflict and Harmony in Education in Tropical Africa. 1975, p. 257.

38) M. Csapo, "Religious, Social and Economic Factors Hindering the Education of Girls in Northern Nigeria", in Comparative Education, Vol, 17, No 3, 1981, p. 311.

39) A. Haroun, "The North and Nigerian Unity: Some Reflections on the Political - Social Problems of Northern Nigeria", Lagos, Daily Times, Fab. 2, 1973.

40) Nos. $6 \& 7$ are additions to these factors by J. Hake, parental attitudes towards women's education in Kano, Unpublished Thesis, ABU, Zaria 1970, and P. Ndugbueze, Need for achievement for girls in Benue Plateau State, Unpublished Thesis, ABU, Zaria, 1973, respectively.

41) Fafunwa, 1974, Quoted in Csapo, p. 312.

42) Csapo, p. 312.

43) R. Levy, The Social Structure of Islam, Cambridge, CUP, 1965.

44) J. Sabe, Attitudes of Parents Towards Education of girls in Adiko district, Benue Plateau State, Unpublished Thesis, ABU, Zaria, 1975.

45) Levy, 1965.

46) See Ibu Khaldun, Prolegomen vol. 1, 354 Quartermere. M. (ed). 1858, in Csapo, P. 314.

47) L. Gaya, Parental attitudes towards Women's Education in Kano, unpublished thesis, ABU, Zania, 1979.

48) Fafunwa, pp. 49 - 50.

49) Fafunwa, p. 71.

50) Fafunwa, p. 78.

51) Fafunwa, p. 92.

52) See Fafunwa, p. 100.

53) Sir F.D. Lugard, "Report on the Amalgamation of Northern and Southern Nigeria and Administration, 1912, - 1919”, Cmd 486 (HMSO) 1920 , p. 60.

54) Sir Frederick Lugard was High Commissioner of Northern Nigeria following the revocation of the Charter of the Royal Niger Company in 1899, until Dec. 31, 1913 on the eve of the amalgamation of 1 January 1914.
55) Lugard, Report on Amalgamation, p. 119.

56) The following tittles of articles on the Almajiri give an insight into this: "Education and the Right to Development of the Child in Northern Nigeria, A Proposal for Reforming the Almajiri Institution", The Almajiri System of Education in Nigeria Today, History of Almajiri Educational System, Universal Basic Education Commission, Almajiri Education Programme, etc.

57) See Fowoyo Joseph Taiwo, Transforming the Almajiri Education for the Benefit of the Nigerian Society, "Social Research, MCSER Publ; Rome Italy, Vol. 3 No 2, Nov. 2013, pp. 67- 72.Thomas Imondu Gomment and Obi Success Esomchi, "Breeding Future Terrorists: A Study of Almajiri of Northern Nigeria and Islamist Militia, in Conflict Studies Quarterly, Issue 18, Jan. 2017, pp. 80 - 92. See also Prof. Idris A. Abdulqadir," The Almajiri System of Education in Nigeria Today", in

http://www.gamisic.com/article5000/NEWS 5956.htm.

58) See History of Almajiri Educational System, in https://naijainfoman.wordpress.com / 2012/ 06 / 07/ history of almajiri-educational - system.

59) See Mike Odeh James, Mikeodehjames@gmail.comin LEADERSHIP.

60) See Abdulqadir, cited, see also Magashi, cited, p 75 , He then gives the number as 10.5 million.

61) See https://naijainfoman.wordpress.com /2012/06/07/ history - of almajiri - educational system.

62) Magashi, P.74

63) See Organization of African Unity African Charter on the Rights and Welfare of the Child, 11 July 1990 CAB/LEG/84.9/49 (1990) available at http://www.refworld.og/docid/zae6b38c/8.htmi.

64) Magashi, P. 75

65) See

UNICEF 2011: http://www.unicef.org./nigeria/child-rightslegislation-in-Nigeria.pdf.

66) A.A. Ali, "Varsities as Agents of National Integration," in National Concord, 5 July 1988, P. 3. 6 July 1988, P. 3.

67) Ali, Ibid.

68) See N. Okafor, The Development of Universities in Nigeria, London, $\quad$ Longman, 1971, P. 119

69) Ali, Cited.

70) Philip A. Akpan, "The Role of Higher Education in National Integration in Nigeria", in Higher Education, Vol. 19, No3, 1990, P. 296. 
71) Akpan. Pp 296-297.

72) See National Universities Commission portal on http://nuc.edu.ng. Accessed 02/22/2017.

73) O. Nnoli, "Education and Ethnic Politics in Nigeria" in African Development, 1.3, 1976, 3753.

74) Akpan, P. 301

75) For details of the Instrumentalist paradigm of social analysis. See Bonny Ibhawoh, Beyond Instrumentalism and Constructivism: Reconceptualising Ethnic Identities in Africa", Paper presented at $55^{\text {th }}$ Annual Congress of Historical Society of Nigeria, ABU, Zaria, 25-27 Oct, 2010. 